\title{
SKRIFGESAG EN SKRIFBEROEP IN DIE ETIEK
}

P.W. Buys

Departement Dogmatologiese vakke, PU vir $\mathrm{CHO}$

\section{ABSTRACT}

The issue that is dealt with in this paper centres on the ways in which the centuries-old Biblical principles and norms in ethics should be applied after twenty and more centuries within a totally different, modern cultural situation. This issue has become especially topical since 1970 when Kuitert, in his article Het Schriftberoep in de Ethiek, maintained that the Scriptural injunction in practice seemed to be a monumentally arbitrary injunction.

Following a historical survey in which the problematizing of Scriptural authority, exegesis and injunction are dealt with, the following guidelines are offered which should be considered in the Scriptural injunction in ethics:

- The Bible is the authoritative, always valid Word of God.

- A distinction should be made between descriptive and prescriptive elements in the Bible.

- The revelation-historical character of the Bible should be respected.

- There is coherence, but also difference between the Old and the New Testaments.

- The decalogue has:

A national but also a universal character

Koers $5 ?(?)$ I0.E 
A positive and a negative character

\section{A permanent character}

- The decalogue is the concrete embodiment of the love commandment.

- Law and Gospel are not opposites but the Law is fulfilled in the Gospel.

- In issues about which Scripture does not offer explicit guidelines, the ethicist has to be guided by the analogia fidei.

1. INLEIDING

\subsection{Objek en aktuditeit van die ondersoek}

Die Bybel is die gesaghebbende Woord van God (NGB art 5). In die Bybel, se die NGB (art 7), word die hele wyse waarop God deur die gelowiges gedien moet word, breedvoerig beskryf.

Hierdie "breedvoerige beskrywing" waarvan die NGB praat, het in die twintigste eeu en veral in die afgelope dekades talle ernstige probleme en vrae opgeroep.

Dit was reeds so vroeg as 1910 dat Chantepie de la Saussaye Jr (1910:26), hom oor hierdie saak soos volg uitgelaat het: "De toestanden dier dagen (naamlik van die Nuwe Testunent - PWB) versclillen zozeer van de onze, dat woorden, daarop berekend, niet zonder meer voor ons gelden. Van hoeveel matschappelijke problemen, die de zwaarste zedelijke eischen stellen, had men voor 19 eeuwen geen begrip."

In 1918 was dit Bavinck (1918) wat daarop gewys het dat die moraal van die NT geskryf is vanuit die standpunt van die verdrukte en vervolgde gemeente wat nog so goed as geen kultuurtaak in die wereld kon volbring nie. Toe die omstandighede verander het, het 'n ander houding nodig 
geword. Na beginsel en wese bly dieselfde voorskrifte geld, maar in die konkrete toepassing dwing die veranderde omstandighede tot wysiging.

In 1939 het Koopmans $(1939: 190)$ 'n artikel onder die opskrif "Het beroep op de Heilige Schrift" gepubliseer. Hy het die etiese vraagstukke van destyds as eersterangse probleme beskou "nu het christelijk karakter der Westeuropese samenleving verloren is gegaan". Volgens hom is dit die roeping van die kerk om die strekking van die evangelie met betrekking tot etiese, kerklike, politieke en sosiale vraagstukke konkreet te preek. Dit wil sé die huwelikslewe, die politiek, die sakemoraal sal met die oog op die ontkerstening van die lewensorde met groter erns as in die verlede onder die beslag van die evangelie gebring moet word.

In 1955 het Schippers (1955:149) verklaar dat die soek en vind van Bybelse antwoorde op eietydse etiese vraagstukke "uitermate moeilijk" is en wel om twee redes. Die eerste is dat die eietydse lewe so ver weg staan van die lewe wat in die Skrif geteken word. Die tweede is omdat die lewe met sy vraagstukke die Skrifstudie dikwels baie ver vooruit is.

Kuitert (1970:71) het onder die opskrif "Het Schriftberoep in de ethiek" in 1970 die stelling gemaak dat die Skrifberoep in die praktyk blyk "een kolossaal willekeurig beroep te zijn". Sy standpunt is dat die etikus hom glad nie direk op die Skrif kan beroep nie omdat die Bybel slegs 'n oorlewering is van die ervaring wat die Bybelskrywers van God gehad het. Daarom kies Kuitert wat hy noem 'n indirekte beroep op die Skrif.

Ewe-eens in 1970 skryf Van Unnik (1970:7) dat die kader waarin die woorde van die Nuwe Testament gespreek is en die vrae wat gevra word op ekonomiese, staatkundige, kulturele en godsdienstige gebied, so totaal anders as die eietydse is dat aan 'n eenvoudige natrek van die lyne nie gedink kan word nie.

Botha (1976:208) skryf onder die gelykluidende titel "Skrifberoep in die Christelike Etiek" dat aanwending van die Skrif as norm vir elke aspek van die sedelike lewe nie ' $n$ eenvoudige saak is nie. Daarvoor is, wat hy noem die historiese karakter van die Skrif, enersyds, en die talrykheid van die eietydse situasies wat buite die gesigsveld van die Bybel lè, andersyds, verantwoordelik. Engelbrecht $(1979: 13)$ noem dit 
die "basiese probleem van die teologiese Etiek" en formuleer die probleem vragenderwys: "Wat is die verhouding tussen die Bybel en die etiese besluitneming en gevolglik die sedelike lewe (van die gelowige of van die mens en matskappy in die algemeen)?"

Verhoef $(1978: 519$ v) stel die vraag: "Is Ou-Testamentiese voorskrifte vandag nog bindend?" en dan maak hy gewag van groot verwarring wat daar onder kerklidmate bestaan oor Ou Testamentiese uitsprake oor die sabbat, die dra van vrouensklere deur mans (en omgekeerd) en borgstaan.

Coetzee, De Klerk en Floor (1980:18) bespreek die "Hermeneuse van die Skrif met die oog op hedendaagse kerklik-etiese vraagstukke" en sinjaleer "resente verskuiwinge in die hermeneuse van die Heilige Skrif". 'n Veranderde Skritbeskouing, sê hulle, het die Bybei gedegradeer van 'n openbaringsboek tot 'n ervaringsboek, nie meer die Woord van God nie maar 'n woord oor God, 'n oorlewering van hoe mense 2000 jaar gelede cor God gedink het, 'n tradisie so grys van ouderdom dat dit by die oplossing van die eietydse etiese vraagstukke geen direkte betekenis het nie.

Onder die opskrif "Skrifberoep in die Etiek" stel Heyns (1982:150) wat hy noem die onvernydelike vraag "of die ganse etiese openbaringsinhoud van die Skrif onverminderd en onveranderd ook vir ons vandag nog geldig is? As ons vandag in talle opsigte nie (meer) handel soos Israel in die Ou Testament of soos Christene van die vroeë kerk nie, en hulle gehandel het volgens die uitdruklike opdragte van God self, is ons dan ongehoorsaam aan die Skrif? Terwyl ons baie nie meer doen nie, en ook baie méér doen, en daar dus baie weggeval en heelwat ook bygekom het, is die ernstige gewetensvraag of ons voldoende Skrifgronde het vir wat ons nie meer doen nie en vir wat ons wel doen? Lê aan hierdie hantering van en beroep op die Skrif nie ' $n$ ongenormeerde willekeur ten grondslag nie, of vind dit tog plaas volgens 'n definitiewe sisteem van hermeneutiese beginsels?"

Om alles kort saam te vat. Hoe moet die gelowige etikus aan die vooraand van die een en twintigste eeu die Skrif hanteer om tol helderheid te kum oor wat in 'n bepaalde situasie die wil van God vir sy doen en late is?

$-429-$ 
Dat dit ' $n$ brandend aktuele vraagstuk is, behoef na die aanhalings van resente uitsprake wat hierbo gemaak is, seker geen verdere betoog nie.

\subsection{Doel van die ondersoek}

Hoe dieper ' $n$ mens in hierdie vraagstuk delf, hoe meer kom jy onder die indruk van hoe gekompliseerd dit eintlik is. Dit gaan hier om fundamentele kwessies: Die gesag van die Skrif as onfeilbare en genoegsame Woord van God. Dit gaan voorts om hermeneutiek, eksegese en hermeneuse van die Skrif. Dit gaan ook om die verhouding tussen Ou en Nuwe Testament. Uiteraard kan in die kort bestek van hierdie voordrag nie op al hierdie sake grondig ingegaan word nie. Wat hier gebied word, sal hoogstens 'n paar grondreëls wees met die oog op 'n sinvolle, verantwoorde Skrifberoep in die etiek.

\subsection{Werkplan}

$\mathrm{Na}$ hierdie Inleiding sal dit nodig wees om 'n kort historiese oorsig te gee waarin agtereenvolgens gelet word op die problematisering van die Skrifgesag sedert veral die agtiende eeu, die problematisering van die Skrifverklaring in die twintigste eeu op die voetspoor van Bultmann, en die problematisering van die Skrifberoep by Kuitert. Daana sal in tetiese beskouing gegee word oor die gesag van dip Skrif as die geloofsvertrekpunt vir die Gereformeerde etikus. As dit vasstaan, moet gehandel word oor die verklaring van die Skrif. Daaronder moet met die oog op die Skrifberoep in die etiek rekening gehou word met die onderskeiding geskiedenis en voorskrifte in die Bybel, die Bybel as openbaringshistoriese boek, die samehang en verskil tussen die Ou en Nuwe Testament. Vervolgens word die aandag nader toegespits op die karakter van die dekaloog en uiteindelik sal die verhouding wet en evangelie ter sprake kom om af te sluit met 'n samvattende konklusie. 


\section{2. 'N KORT HISTORIESE OORSIG OOR DIE PROBLEEM}

\subsection{Problematisering van die Skrifgesag}

Tot met die sestiende eeuse Reformasie is die gesag van die Skrif allerweë erken. Rome het wel nie die genoegsaamheid van die Skrif gehandhaaf nie maar naas die Skrif ook die tradisie bestaande uit die Apokriewe boeke, die uitsprake van die kerkvaders; die besluite van kerklike vergaderings en pouslike dekrete as gesaghebbend aanvaar. Maar die gesag van die Skrif is nooit deur Rome ontken nie.

In die sewentiende eeu het die Skrifkritiek begin opkom. Met die Rasionalisme in die agtiende eeu is dit voortgesit. In die negentiende eeu was dit Schleiermacher wat met sy "Ueber den sogenannten ersten Brief des Paulus an den Timotheus" (1807) die eintlike aanslag op die outentisiteit van die verskillende Bybelboeke van stapel gestuur het. Dit het 'n hoogtepunt bereik in die skeptisisme van die Tübingenskool van F.C. Baur en is voortgesit deur die Modernistiese Hollandse Radikale Skool van A.D. Loman wat die outentisiteit van feitlik die hele Bybel geloën het.

Vanuit heeltemal ' $n$ ander hoek wurd die Skrifgesag in die twintigste eeu geproblematiseer. Vir die doel van hierdie studie hoef slegs na die Skrifbeskouing van Kuitert verwys te word. Die Skrif het volgens hom alleen tradisionele gesag. Die Bybel is in vertelling van die ervarings wat mense baie eeue gelede gehad het. Dis 'n stuk oorlewering, 'n stuk tradisie. "De bijbel is de christelijke traditie van mensen uit het verleden, mensen van 1900 jaar geleden, zelfs van 2000 jaar geleden, die in hun termen over God spreken." (1976:10.)

Daarmee is die saak van Skrifberoep erg geproblematiseer. Wat is die waarde van 'n beroep op 'n Bybel waarvan die egtheid en die Goddelike gesag nie vasstaan nie? 


\subsection{Problematisering van die Skrifverklaring}

In die twintigste eeu het daar 'n belangrike aksentverskuiwing plaasgevind vanaf die vraag oor die outentisiteit na die vraag oor die gesag van die Skrif. Dit was Bultmann (vgl. Velema 1971:16) wat die fokus op die hermeneutiek saamgetrek het. Nie wat ' $n$ teks in die verlede vir die skrywer en vir die leser beteken het, is belangrik nie, maar wat hy vandag vir die leser met sy bepaalde lewensmilieu beteken - daar gaan dit om in die hermeneutiek. Die subjektiewe begrip van die leser is die hooffaktor in die verstaansproses. Om die subjektiwiteit van die mens tot sy reg te laat kom, is wat die hermeneutiese teologie, waarvan Bultmann die inisieerder is, beoog.

Vir die Skrifberoep in die etiek is hierdie hermeneutiese teologie van groot negatiewe betekenis. Natuurlik sit in hierdie teologie 'n element van waarheid. 'n Hollander of Duitser uit 'n eeu-oue teologiese beskawingsagtergrond sal die Bybel sekerlik met ander insigte lees as iemand wat in die kultuurmilieu van Swart Afrika groot geword en maar onlangs vir die eerste keer in sy lewe die evangelie gehoor het. Feit is egter dat albei as gevolg van die duidelikheid van die Skrif die kernboodskap van verlossing daaruit kan aflees en verstaan. In sy werk "De realiteit van het geloof" het Kuitert tereg skerp kritiek op die eksistensialisme in hierdie hermeneutiese teologie gelewer. Volgens Kuitert val daar in die selfverstaan van die mens ' $n$ voorbeslissing waardeur die spreke van God nie tot sy reg kan kom nie. Die subjektiewe filter van die leser se lewenservaring word 'n struikelblok waardeur die openbaring van God se wil aan bande gelè word. Slegs dit wat die leser vanuit sy eie lewensmilieu aanvaarbaar vind en wat vir hom belangrik is, neem hy aan en die res laat hy by hom verbygaan. Die subjektiewe element word hier so op die spits gedryf dat die duidelikheid van die Skrif ingeboet word. Vir die Skrifberoep in die etiek het die subjektivisme funeste gevolge. Die subjektiewe leser laat die Skrif in etiese vraagstukke buikspreek sodat die Skrif elke keer presies 'n uitspraak lewer wat al by voorbat in die gemoed van die leser 'n uitgemaakte saak was. Op hierdie manier kan 'n mens enigiets wat deur die Bybel verbied word, van homoseksualisme tot egskeiding, vanuit jou subjektiewe lewenskader reg redeneer en in jou kraam laat pas. 


\subsection{Problematisering van die Skrifberoep}

Dit is nogal ironies dat dieselfue Kuitert wat so 'n skerpsinnige bestryding van die eksistensialistiese hermeneutiese teologie van Bultmann gelewer hel, toe in 'n ander uiterste verval het. In 'n artikel wat nou al histories geword het onder die titel "Het Schriftberoep in de ethiek" (in Anders gezegd), het Kuitert in 1970 ' $n$ groot gefladder in die Gereformeerde duiwehok aan die gang gesit. Die hoofsake in genoemde artikel is die volgende:

* Die Skrifberoep het nèrens so problematies geword nie as by die vraag: Wat moet ons doen? Dit blyk dat Christene vandag heeltemal anders handel, ook in etiese opsig, as die volk van God onder die Ou Verbond of die eerste Nuwe Testamentiese gemeente. Vandag doen Christene baie dinge nie meer wat toe vanselfsprekend was, deur die wet van God gereël en selfs uitdruklik voorgeskryf was. Die doen van sekere dinge vandag wat God destyds aan Israel voorgeskryf het, sou in die eietydse Christelike gemeente opspraak verwek en om sensuur geroep het. Die verhouding man-vrou (soos byvoorbeeld in Numeri 5 gereël), die uitsprake oor slawerny en die agrariese wetgewing by Israel kan as voorbeelde dien (Kuitert, 1970:67-70).

* Na bogenoemde drie voorbeelde stel Kuitert wat volgens hom die kern van die probleem is: "Het Schriftberoep blijkt in de praktijk een kolossaal willekeurig beroep te zijn. Met willekeurig is bedoeld: niet héel de Schrift staat kennelijk open voor een beroep, doch slechts bepaalde stukken. Teksten, flarden van teksten soms, functioneren; andere teksten functioneren niet en in vele gevallen nooit. De vraag is nu: is het werkelijk volstrekt willekeurig, wat we in het Schriftberoep in de ethiek tegenkomen, of zit er achter dat op het eerste gosicht zo willekeurige beroep toch een systeem, en achter dat systeem weer een hermeneutisch standpunt?" (1970;71.)

* Vervolgeris wys Kuitert (1970:71) die onderskeiding tussen seremoniële wette, burgerlike wette en sedewet wat eeuelank aan die sisteem van die Gereformeerde Skrifberoep by die OT in die etiek ten grondslag gelè het, van die hand. As vourbeelde van onhoudbare Skrifberoep in hierdie 
kader noem hy Calvyn se hantering van die renteverbod en die sabbatskwessie in die Gereformeerde etiek.

* Maar volgens Kuitert is daar nóg ' $n$ wurm wat aan die sisteem knaag, naamlik die vraag: wat mak moreel eintlik tot moreel? Dit wil sè: wanneer is 'n Ou Testamentiese gebod burgerlik, wanneer is dit seremonieel en wanneer is dit sedelik? Is die renteverbod ' $n$ burgerlike wet omdat Calvyn so sê? En waarom word die huwelikswetgewing as burgerlik en nie as sedelik beskou nie? Die gevolg is volgens Kuitert, in sy eie woorde, dat die Gereformeerde etici dusver "met heel het fijn vertakte systeem van hun hermeneutiek eigenlijk niets anders deden dan van de totaliteit van de bijbelse geboden afschrappen wat ze niet gebruiken konden en overhouden wat naar hun beste weten nodig was voor de menselijke samenleving van hun eigen tijd ... De hermeneutiek bestond er dus in om met behulp van de onderscheiding tussen ceremoniöle, burgerlijke en morele wetten, en vooral: met behulp van het in alle vrijheid onderbrengen van bepaalde geboden bij een bepaalde groep wetten, in en vanuit de bestaande praktijk en haar vereisten klaar te komen met die bijbelse geboden. Al deze omslachtigen redeneringen waren evenzovele verantwoordingen waarom het Schriftberoep in het ene geval wel en in het andere niet geldig was." (Kuitert, 1970:74.)

* Kuitert konkludeer dat hy hierdie beweerde willekeur van die Skrifberoep in die etiek aan die kaak stel juis $\mathrm{cm}$ die Skrif teen misbruik te vrywaar. As 'n mens die Skrif nie na sy eie-aard verstaan nie, werk iv mee aan die verlies van respek vir die Skrif. Goedbedoelde maar willekeurige beroep op die Skrif is, volgens Kuitert, in vorm van Biblisisme. Hierdie willekeurige Skrifberoep wat die Skrif nie volgens sy ware aard hanteer nie, is atomisties en kan daarom nie aandui waarom daar ' $n$ beroep op sommige tekste gedoen word en op ander nie.

Wat stel Kuitert voor is dan die regte wyse van Skrifberoep? Kuitert wil van 'n direkte Skrifberoep op bepaalde Skrifuitsprake niks weet nie. Dit is volgens hom nie inoontlik om bepaalde skrifuitsprake as bewysplekke op eietydse situasies toe te pas nie. Volgens Kuitert is die "meest verantwoorde hermeneutische greep" (1970:12) op die Bybelse gebooie die indirekte Skrifberoep. Wat moet daaronder verstaan word? In die Bybelse gebooie, sê Kuitert (1970:12) "krijgen wij ... informatie $-434-$ 
over Gods bedoeling met mens en wereld, zoals die bedoeling in een bepaalde tijd (en dat variëert in de Schrift zelf reeds aanmerkelijk) is verstaan en gehoorzaand". Hierdie aanduidings is voorbeelde en modelle wat in die hede herhaalbaar kan wees of nie. So word die Skrif nie in die verlede opgesluit nie maar word die pad oopgemaak om dit in die hede te laat funksioneer. So, sè Kuitert (1970:86), word enersyds die onveranderlikheid van God se wil verdiskonteer, sonder om onhistories te word, en andersyds word die historisiteit van die Bybelse paranese gehandhaaf sonder om in 'n reèlregte situasie-etiek te verval.

Daarby stel Kuitert (1970:86) die eis dat die Bybelse gegewens in gebod en evangelie geontsosialiseer moet word. Byvoorbeeld, die verdwyning van die patriargale leefwyse het tot gevolg dat die term vader ' $n$ betekenisverandering ondergaan het. Daarom kan die Bybelse vadernaam van God nie vandag meer op dieselfde manier as eeue gelede sè wie God die Vader eintlik is nie.

Die gemeente moet volgens Kuitert (1970:87) die instansie wees wat deur die Heilige Gees betrek word in 'n dialoog met die Skrif as kanon oor die vraag wat vandag gehoorsaamheid aan God se gebod sal wees. Indirekte Skrifberoep in die etiek is dus ' $n$ beroep op wat die gemeente in sy Christelike bewussyn oor bepaalde etiese kwessies dink.

Kuitert se beskouing oor Skrifberoep in die etiek is deur Douma (1975) in sy brosjure "Voorbeeld of gebod?" grondig weerlè. Die vernaamste punte warop hierdie kritiek neerkom, is die volgende:

* Die Bybel bevat nie 'n chaos van gebooie soos Kuitert beweer nie. Dit word duidelik as 'n mens daarop let hoe Paulus, een van die laaste Bybelskrywers, sy weg daardeur vind.

* By Kuitert is daar haas geen vorskil tussen die Christelike en die heidense moraal nie. Maar dit strook nie met wat die Skrif byvoorbeeld by monde van Paulus (Rom 1) oor die verskriklike verdorwenheid van die heidene leer nie.

* Kuitert se stelling dat die Skrif net voorbeelde en nie ook voorskrifte vir vandag gee nie, strook nie met die werklikheid nie. Paulus roep op $-435-$ 
tot gehoorsaamheid aan ouers en owerhede, liefde tussen man en vrou dit geld vandag net soseer as toe Paulus dit geskryf het.

* Die wet is nie 'n heilsweg nie maar 'n lewensnorm.

* Die Tien Gebooie bly geldig as reël van dankbaarheid ook al is die hele wet deur Christus vervul.

By bogenoemde punte kan ook nog die volgende uit Stoker (1986) se kritiese studie onder die titel "Direk of indirek?" gevoeg word:

* Kuitert se siening van die Skrif as neergeskrewe menslike ervarings van God, breek die gesag van die Skrif af en maak Skrifberoep in die etiek irrelevant.

* Om tot 'n korrekte wyse van Skrifberoep te kom moet die hermeneutiese model wat die Skrif self gee, gevolg word. So 'n Skriftuurlike model gaan uit van die eenheid van die Skrif (wat Skrif-met-Skrif-vergelyking 'n eis maak), die tydgerigtheid, gesagvolheid, deursigtigheid, genoegsamheid en geinspireerdheid van die Skrif.

Met hierdie laaste kritiekpunt begin Stoker eintlik om te se: as die weg wat Kuitert aangedui het, nie die regte weg is nie, hoe lyk die regte weg dan wel?

Daaraan sal vervolgens aandag gegee word.

\section{DIE GESAG VAN DIE SKRIF}

\subsection{Die Bybel as die Woord van God}

As absolute uitgangspunt by die kwessie van Skrifberoep in die etiek moet die gesag van die Skrif as die onfellbare Woord van God voorop gestel word (art 5 NGB). As 'n organiese geheel wat oor nagenoeg 1500 jaar tot ' $n$ eenheid gegroei het, getuig die Skrif van homself dat hy as in geheel deur God ingegee is (2. Tim 3:16). 
Die aanvaarding van die Bybel as onfeilbare gesaghebbende Woord van God is vir die Gereformeerde etikus geloofsuitgangspunt. Bavinck (1906:634) het hom daaroor soos volg uitgespreek: "De autoriteit der Schrift rust in zichzelve en is voor geen bewijs vatbaar. De H. Schrift is autopistos en daarom de laatste grond des geloofs. Een diepere grond is niet aan te voeren ... De band der ziel aan de Schrift als het woord Gods ligt achter het bewustzijn, en onder het bewustsijn; hij is mystiek van aard, evenals het geloof aan de principia in de verschillende wetenschappen."

In verband met hierdie mistieke element by die aanvaarding van die Bybel as Woord van God vra Totius $(1977: 12)$ by wyse van toeligtende voorbeeld: "Hoe weet 'n lammetjie, al van die eerste dag af, dat sy ma sy ma is? Wel omdat dit sy ma is! Hoe weet ek dat die stem van my vader, wat honderde en duisende myle ver tot my kom oor foon of radio, die stem van my vader is? Wel, ondat dit die stem van my vader is 1 Bewys het ek nie nodig nie. Kontroleer kan ek dit op die oomblik ook nie, want ek kan nie hier en daar tegelyk wees nie."

Dit is die boeremanier om te sé wat daar in die Nederlandse Geloofsbelydenis (art 5) staan: "Ons glo ook sonder twyfel alles wat daarin (die kanonieke boeke - PWB) vervat is ... omdat die Heilige Gees in ons hart getuig dat hulle van God is."

\subsection{Die verklaring en toepassing van die Bybel}

As dit eenmal vasstaan dat die Bybel die onfeilbare Woord van God is, moet daar nou aandag gegee word aan die vraag: hoe moet die onfeilbare Woord van God verklaar word? Dit gaan dus om hermeneutiek (die wetenskap van Skrifverklaring) eksegese (die uitleg van die Skrif) en hermeneuse (die oorbring van die Skrifboodskap in die eietydse situasie).

In hierdie verband word verwys na die uitmemende artikel van Coetzee, De Klerk en Floor: Die hermeneuse van die skrif met die oog op hedendaagse kerklik-etiese vraagstukke (Koers 45:1; p 18-36). In hierdie artikel word die relevante hermeneutiese vertrekpunte (aksionas) gegee. As basiese uitgangspunt word gestel dat die Bybel die ewige en -437 - 
altyd geldende Woord van God is, dat die Skrif deursigtig is, dat die Skrif nie tydgebonde nie maar tydgerig is, dat Skrif met Skrif vergelyk moet word by die verklaring van die Skrif, dat daar steeds van die duidelike na die minder duidelike beweeg moet word, dat die Heilige Gees Inspirator en Eksegeet is, dat die belydenisskrifte bindend is vir die eksegeet, dat die skopus (gerigtheid) van die Skrif in ag geneem moet word, en dat met die Bybelse perspektief op die eietydse situasie hermeneuse bedryf moet word.

In hierdie verband kan verder na Heyns (1982:1592) se tien Bybelse koördinate waardeur die etikus in sy Skrifberoep gelei moet word, verwys word. Hy gee die volgende kontekste:

- die goddelike gesag

- die verbond

- die historiese volksbestaan

- die historiese volkereverhouding

- die historiese heilsopenbaring

- blywende en wisselende elemente

- gehoorsaamheidsmodelle en -norme

- die leidende werksaamheid van die Gees en die kreatiewe werksaamheid van die gelowige

- die totale bedoeling van die openbaring

- die totale ruimte van die openbaring

In aansluiting by die voorgenoemde die volgende.

\subsubsection{Geskiedenis en voorskrif in die Bybel}

Die Skrif bevat geskiedenis en voorskrifte. Dié twee mag by die Skrifberoep in die etiek nie verwar word nie. In Nederland is daar van oudsher in die Bybel onderskei tussen "er is geschreven" en "het is geschiedt". Eersgenoemde is normatief, imperatief, laasgenoemde is beskrywend, indikatief. Die dade van mense wat in die Godsopenbaring beskryf word, is nie noodwendig goed nie. Soms word juis hul slegte dade vermeld sonder dat die Skrif hom ter plaatse eksplisiet afkeurend daaroor uitspreek. ' $n$ Mens mag jou in die etiek nie daarop beroep dat Abraham, die vader van die gelowiges, as gevolg van Sara se -438 - 
kinderloosheid Hagar as bywyf geneem het (Gen 16:1 v) of dat Dawid, die man na God se hart, sewe seuns van Saul laat ophang het nie (2 Sam $21: 8,9)$

\subsubsection{Die Bybel as openbaringshistoriese boek}

God het sy Woord nie as 'n diktaat uit die hemel gegee nie. Hy het Homself op verskillende maniere aan mense deur die loop van baie eeue geopenbaar. Ook sy geopenbaarde wil ten opsigte van wat die gelowige moet doen om God welbehaaglik te lewe, het 'n openbaringsgang deurloop. Calvyn $(1890,11, X 1,13)$ het by sy uiteensetting van die verskille tussen die $\mathrm{Ou}$ en Nuwe Testament daarop gewys dat daar sommige mense is wat dit as ' $n$ ongerymdheid beskou dat God wat altyd aan Homself gelyk bly. dit wat Hy eenmaal gebied het, later sou afkeur. Daarop antwoord Calvyn dat ' $n$ mens nie moet dink dat God veranderlik is omdat $H y$ op verskillende tye verskillende maniere van onderrig gegee het nie, maar dat God geweet het wat vir elkeen nodig is. As 'n boer sy gesin ander werksaamhede in die winter as in die somer laat verrig, dan sal ' $n$ mens hom tog nie van wispelturigheid beskuldig nie of dink dat hy van die regte reäl van die landbou afgewyk het wat met die voortdurende orde van die natuur saamhang nie. As ' $n$ huisvader sy kinders in hul kleinkinderdae anders as in hul puberteit of hul adolessensie regeer en behandel, dan moet 'n mens nie daarom sè dat hy wispelturig is of van sy standpunt afwyk nie. Waarom beskuldig mense God dan van wispelturigheid omdat $\mathrm{Hy}$ die verskil van die tye deur geskikte en passende tekens onderskei? Tot sover Calvyn.

Vir die etikus wat hom op die Skrif wil beroep, is dit van die allergrootste belang om daarmee rekening te hou of die teks waarop hy hom beroep, in Levitikus of in 2 Timoteus staan.

\subsubsection{Samehang en verskil tussen $O u$ en Nuwe Testament}

Wat onder 3.2.2 hierbo gesè is, impliseer dat daar anders na die Ou as na die Nuwe Testament gekyk moet word. Dis een Bybel maar twee testamente. Die Ou Testament is die bedeling van die beloftes, die skadubeelde, die seremonies wat heenwys na die koms van Christus. $-439-$ 
Die Nuwe Testament is die bedeling van die vervulling in Christus van die dinge wat in die Ou Testament geprofeteer, afgeskadu en versinnebeeld is. In verband met die Skrifberoep op die Ou Testament toon Verhoef $(1978 ; 557 \mathrm{v})$ voortreflik aan dat die etiese uitsprake van die Ou Testament sover moontlik altyd by die lig van die Nuwe Testament gelees moet word. So word, om maar een voorbeeld te noem, homoseksualisme nie net in die Ou Testament nie (Lev 18:22; 20:13) maar ook in die Nuwe (Rom 1:26, 27) verbied as strydig met die wil van God. Baie van die Ou Testamentiese voorskrifte het met die skeuring van die voorhangsel verval (Mat 27:51) ondat hulle in Christus vervul is. Ander Ou Testamentiese voorskrifte geld na die voldoeningswerk van Christus as reël van dankbaarheid.

Wat die OT betref: Calvyn en talle Gereformeerdes na hom het gebruik gemaak van die driedeling seremoniële, burgerlike en sedewet. (Vgl. Ursinus, 1978:236; Polman, s.j.:168.) Hierdie driedeling word ook in die Nederlandse Geloofsbelydenis (art 25) en die Heidelbergse Kategismus (Sondag 34) verdiskonteer. Die besware wat Kuitert en andere deesdae teen hierdie driedeling het, geld sekerlik van die misbruik wat moontlik van die driedeling gemaak is. Maar is dit nou reg om die kind saam met die badwater uit te gooi? Dan eindig jy saam met Kuitert by wat vir hom na 'n chaos van gebooie in die Ou Testament lyk.

Die feit kan tog nie ontken word dat sekere gebooie in die Ou Testament 'n suiwer etiese karakter het (Eks 20), dat ander beslis op die burgerlike lewe van Is rael betrekking het (vgl. Deut 16:18-17:20) en dat ander die seremonies van die erediens voorskryf nie (Lev 1-27). Natuurlik is daar ook voorskrifte wat moeilik net by een van die drie kategorieë ingedeel kan word omdat hulle byvoorbeeld sowel 'n sedelike as 'n seremoniële of 'n burgerlike inslag het.

Die goeie gebruik van hierdie onderskeiding bly myns insiens vir die Skrifberoep in die etiek noodsaaklik.

\subsubsection{Karakter van die dekaloog}

In die Ou Testament vorm die dekaloog die kern van die etiese voorskrifte wat God aan Israel gee. 
Die etikus wat hom op die sedewet, soos in die dekaloog saamgevat, wil beroep, moet met die volgende karaktertrekke van die dekaloog rekening hou.

\subsubsection{Nasionale en universele karakter}

Die Tien Gebooie is aan Israel gegee toe hul 'n nomadiese woestynvolk was. Daarom gaan dit om ' $n$ os, ' $n$ donkie, ' $n$ beloofde land. Maar die etiese sake waaroor dit handel, gehoorsaamheid, doodslag, egbreuk, diefstal geld vir alle mense van alle tye op alle plekke.

\subsubsection{Sinekdogeïese karakter}

'n Sinekdogee is ' $n$ stylfiguur wat die geheel met ' $n$ deel aandui. In die Ons Vader-gebed word byvoorbeeld gevra om ons daaglikse brood - maar daarmee word alle stoflike behoeftes bedoel. So noem die Tien Gebooie telkens een vorm maar bedoel daarmee alle vorme van die kwaad wat daarmee in verband staan. In sy Bergrede het die Here Jesus hierdie sinekdogeiese karakter so aangewend dat nie net die uitwendige daad nie maar ook die innerlike begeerte reeds al oortreding van die gebod is (Mat 5:22,38). So besien, beslaan die dekaloog 'n ontsaglike wye spektrum van sake sodat selfs eietydse etiese vraagstukke wat op die oog af nie in die gesigsveld van die Bybel opgekom het nie, op een of ander manier tot een of meer van die Tien Gebooie herleibaar is en met ' $n$ beroep daarop beoordeel kan word.

\subsubsection{Positiewe en negatiewe karakter}

Agt van die Tien Gebooie is negatief. Slegs die vierde en vyfde gebod is positief. Die Heidelbergse Kategismus leer dat die negatiewe gebooie nie net die genoemde kwaad verbied nie maar dat dit die positiewe deug gebied (en ongekeerd by die twee positiewe gebooie). Daarmee word die spektruin van die dekaloog dubbel so groot.

\subsubsection{Permanente karakter}

Jesus sè in sy Bergrede dat Hy nie gekom het om die wet te ontbind nie maar dit te vervul. "Want voorwar Ek sè vir julle, voordat die hemel $-441-$ 
en die aarde verby gaan, sal nie een jota of een titteltjie van die wet ooit verbygaan totdat alles gebeur het nie." (Mat 5:18.) Die feit dat Jesus die sesde en sewende gebod in sy Bergrede verklaar, is veelseggend. Die lewe van die burgers in die koninkryk van God moet enduit volgens die koningsbevele van God ingerig word. Vir die Skrifberoep in die etiek is dit van ontsaglike betekenis.

\subsubsection{Die dekaloog as vergestalting van die liefdesgebod}

Eintlik is daar maar een gebod, die groot gebod, die liefde tot God en die naaste. Die liefdesgebod dek 'n onoorsienbare veld en kan seker by alle etiese kwessies as toetssteen aangelé word - ook oor sake waaroor daar in die Bybel geen pertinente uitspraak is nie. Maar die liefde verdwaal maklik, het Calvyn èrens gesè. Daarom het God die Tien Gebooie gegee as bakens langs die pad waarop die liefde moet gaan.

Daar is dus in die etiese handeling enersyds 'n situatiewe element en andersyds 'n kasuistiese element. Die motief van 'n sedelik-goeie daad moet altyd die liefde tot God en die naaste wees. Maar dan moet die liefde hom, waar moontlik, deur die eksplisiete gebod laat lei.

Die liefde tot God veronderstel die geloof in God as bron, die wet van God as maatstaf en die eer van God as doel van die eties goeie handeling. So is dit inderdaad in die Heidelbergse Kategismus (Sondag 33) waar verklaar word: Goeie werke is "slegs die wat uit 'n ware geloof, volgens die wet van God tot sy eer gedoen word".

\subsubsection{Wet en evangelie}

Wet en evangelie mag nooit in 'n valse jukstaposisie as mekaar se teenoorgesteldes geplaas word nie. Daar is reeds op gewys dat Christus in sy Bergrede die lewe van die verloste burgers van die koninkryk onder die tug van die wet plaas. Ook in Paulus se briewe figureer die vraag na die rol wat die wet in die lewe van die Christen moet speel (Rom 3:21-31; 6:6-7; Gal 2:15-17; Fil 3:8-9; 2 Kor 5:21). As Paulus die Christene in Rome vermaan om as verlostes in Christus 'n heilige lewe te lei, beroep hy hom agtereenvolgens op die sewende, die sesde, die -442 - 
agtste en die negende gebod en voeg daarby dat hierdie "en watter ander gebod ook al" in die liefdesgebod saamgevat word (Rom 13:8-14). Verhoef (1978:559) vestig die aandag daarop dat Paulus nèrens in soveel woorde die Christene oproep om die wet te onderhou nie. Hy warsku teen die werke van die vlees en wys op die vrug van die Gees (Gal 5:16-26) en vermaan die Christene om mekaar se laste te dra en so die wet van Christus te vervul (Gal 6:2).

Dit verhinder Paulus nie om talle eksplisiete etiese voorskrifte te gee nie soos in sy eerste brief aan die Korinthiërs waar dit oor broedertwis gaan (hfst 1,6), hoerery (hfst 5,6), huweliksprobleme (hfst 7), vleis wat aan die afgode geoffer is (hfst 8). Ewe eksplisiet in sy etiese uitsprake is Jakobus in sy algemene brief: beheersing van die tong (hfst 3), seksuele losbandigheid (hfst 4), geldsug (hfst 5).

Dit wil nietemin lyk asof Paulus swaar aksent lé op die lewe in Christus in wie die Christen vry is. Maar dan mag die Christen nie sy vryheid misbruik en bandeloos word nie. 'n Wandel deur die Gees, ' $n$ wandel in Christus, is juis ' $n$ wandel waarin die wet van Christus, die wet van die liefde, volbring word. In hierdie sin moet ook Paulus se uitspraak aan die Korinthiërs (1 Kor 6:12) verstaan word: "Alles is my geoorloof, maar nie alles is nuttig nie, alles is my geoorloof, maar ek sal my nie deur iets laat oorheers nie."

\subsubsection{Analogia fidei}

Hierdie uitsprake van Paulus is van besondere belang vir die Skrifberoep in die grys gebied wat Brillenburg-Wurth èrens die gebied van die grensetiek genoem het. Dit is die gebied waarop talle sake voorkom waroor die Skrif hom nie pertinent uitspreek nie. As voorbeelde kan hier genoem word passiewe eutanasie, orgaanoorplanting, kernoorlog, artifisiële inseminasie, proefbuisbabas, surrogaatmoederskap.

Hoe moet die Christen-etikus oor sulke sake waaroor die Skrif niks sé nie, cordeel?

Totius het altyd gesè, as daar oor 'n bepaalde saak nie 'n teks in die Bybel is nie, dan is die hele Bybel nog daar. Die Heilige Gees skep deur -443 - 
die Woord 'n bepaalde geestesklimaat. En die gelowige wie se gewete deur Woord en Gees fyn ingestel word, ontwikkel algaande 'n sensitiewe geloofsintuïsie waardeur hy gou bemerk wanneer iets nie in die Christelike lewensklimaat tuishoort nie. Die Gereformeerde vaders het in hierdie verband van die analogie van die geloof gepraat. Ter illustrasie die volgende praktiese voorbeeld. Daar bestaan 'n staaltjie dat mense President Paul Kruger een aand tydens een van sy besoeke in Europa tot by die deur van 'n nagklub gebring het en hom toe daar wou inneem. Die president het vasgesteek en gesè: "Kyk, ek het 'n Vriend wat my oral vergesel waar ek gaan. Ek is seker dat Hy nie saam met my by hierdie plek sal binnegaan nie. Daarom sal ek ook nie hier ingaan nie." Die geloofs - en liefdesband tussen Christus en die Christen kan deur die werking van Woord en Gees so innig wees dat die Christen veelal intuitief weet wat reg en verkeerd is en. nie vir elke situasie 'n spesifieke Bybelteks nodig het nie. Natuurlik mag hierdie geloofsintuĩsie nooit van die Woord as geheel losgemaak en verabsoluteer word nie - dan ontaard dit in mistisisme.

\section{KONKLUSIE}

Uit die voorgaande het geblyk dat daar in die twintigste eeu in die Gereformeerde teologie in stygende onrus oor die vraagstuk van Skrifberoep in die etiek ontstaan het. Hierdie onrus het by Kuitert in 1970 paroksismale afmetings aangeneem wat saamtrek in die stelling dat die Skrifberoep in die Gereformeerde etiek 'n kolossale willekeurige bedryf is. Hierdie paroksisme hang saam met in veranderde Skrifbeskouing wat daarop neerkom dat die Skrif nie die Woord van God is nie maar ' $n$ woord oor God. Die goeie Gereformeerde pad vorentoe het as vertrekpunt die aprioriese geloofsbelydenis dat die Bybel die gesaghebbende Woord van God is. Die verklaring en toepassing van die Skrif moet rekening hou met die feit dat daar in die Bybel sowel nienormatiewe geskiedenis as normatiewe voorskrifte is, dat die openbaring van God se wil in die doen en late van die mens in eeuelange historiese gang deurloop het, dat daar 'n samehang maar ook 'n verskil tussen die Ou en Nuwe Testament is en dat beroep op die Ou Testament steeds in die lig van die Nuwe Testament gedoen moet word. Voorts moet by die Skrifberoep in die etiek op konsentriese wyse agtereenvolgens rekening gehou word met die liefdesgebod as die kern van God se geopenbaarde -444 - 
wil, die dekaloog as die vergestalting van die liefdesgebod, talle etiese uitsprake in sowel $\mathrm{Ou}$ as Nuwe Testament wat in die verlengde van die dekaloog lè. In etiese vraagstukke waaroor die Skrif swyg, moet die gelowige etikus hom deur die analogia fidei laat lei sonder om dit te verabsoluteer.

\section{BIBLIOGRAFIE}

BAVINCK, H. 1906. Gereformeerde dogmatiek I. Tweede herziene en vermeerderde druk. Kampen : Bos.

BAVINCK, H. 1918. De navolging van Christus en het moderne leven. Schild en pijl nr. 1.

DOUMA, J. 1975. Voorbeeld of gebod? Enkele opmerkingen over het Schriftberoep in de ethick. Ansterdam : Bolland.

BOTHA, A.H. 1976. Skrifberoep in de Christelike etiek: enkele riglyne. Nederduitse Gereformeerde teologiese tydskrif. XVII, 4. September.

CALVIN, J. 1890. Institutie of onderwijzing in den Christelijke Godsdienst, I. Uit Latyn vertaal deur Baum, Cunitz en Reuss. Kampen : Zalsman.

CALVYN, J. 1890. Kyk Calvin

Chantepie DE LA SAUSSAYE P.D. 1910. Het Christelijk leven. Haarlem : Bohn.

COETZEE, J.C., DE KLERK, B.J. en FLOOR, L. 1980. Hermeneuse van die Skrif met die oog op hedendaagse kerklik-etiese vraagstukke. Koers. 45,1

ENGELBRECHT, B.J. 1979. Opmerkings rondom die basiese probleem van die teologiese etiek. Hervormde toologiese studies. 34,3 . 
HEYNS, J.A. 1982. Teologiese etiek, I. Pretoria : N.G. Kerkboekhandel.

KOOPMANS, J. 1939. Het beroep op de Heilige Schrift. (In Onder het Woord.) Amsterdam : Holland.

KUITERT, H.M. 1976. Kerkinformatie van de Gereformeerde kerken in Nederland. Januarie. Leusden : Algemeen kerkelijk Bureau.

KUITERT, H.M. 1968. De realiteit van het geloof. Kampen : Kok.

KUITERT, H.M. 1970. Het Schriftberoep in de ethiek. (In Anders gezegd.) Kampen : Kok.

POLMAN, A.D.R. s.j. Onze Nederlandsche Geloofsbelijdenis, III. Franeker : Wever.

SCHIPPERS, R. 1955. De Gereformeerde zede. Kampen : Kok.

STOKER, H.G. 1986. Direk of indirek? 'n Antwoord op H.M. Kuitert se siening van Skrifberoep in die etiek. PU vir $\mathrm{CHO}$.

TOTIUS. 1977. Die Bybel is die Woord van God. In Versamelde werke, I. Kaapstad : Tafelberg.

URSINUS, Z. 1978. Het schatboek der verklaring over de Heidelbergse Catechismus. Dordrecht : Van den Tol.

VAN UNNIK, W.C. 1970. Het Nieuwe Testament en de ethiek. Kamper Cahiers 14. Kampen : Kok.

VELEMA, W.H. 1971. Aangepaste theologie. Amsterdam : Buijten $\varepsilon$ Schipperheijn.

VERHOEF, P.A. 1978. Is Ou Testamentiese voorskrifte vandag nog bindend? Die Kerkbode, CXXII, 130, 17, 18. 25 Oktober, 1 November. 